[DOI: 10.24214/jecet.A.10.3.39904.]

Juurnal of Enviranmental Science, Computer Science and Engineering \& Technology

An International Peer Review E-3 Journal of Sciences and Technology

Available online at www.jecet.org

Section A: Environmental Science

Research Article

\title{
Enterprising Women's venture in Kamrup (M), Assam, amidst COVID-19
}

\author{
Ms.Rupamoni Saikia and Dr. Momita Goswami Barooah \\ Assam Rajiv Gandhi University of Cooperative Management, Sivasagar, Assam, India
}

Received: 25 July 2021; Revised: 20 August 2021; Accepted: 30 August 2021

\begin{abstract}
In the United States the first female owned business was recorded in the year 1739, when Eliza Lucas Pinckney took over the family's plantations business in South Carolina at the age of 16 years. In the eighteenth and nineteenth centuries, women used to run small businesses that has been attained through inheritance or created business opportunities to sustain livelihood. In India too, one of the first female entrepreneur is Kalpana Saroj. At the age of 16, she started working in a garment factory to support her family. Likewise in Assam, the entrepreneurship ventures initiated by female were conspicuous too. Despite of having several matrilineal tribes, a few have been known on female business owners. Moreover, historically the eastern part of India, especially in Northeast, women used to rank high in their social strata, and worshipped too. It is in this backdrop the spirit of women entrepreneurship of Assam has been evolved defying all odds amidst covid19. The study is basically based on both primary and secondary sources of data. The world economy is in the process of economic revival after the tarnishing effect of the Covid-19 pandemic including Assam. Homecoming picture of lakhs of migrants raised the question of how much capable the Assam economy is of employing this huge workforce. Assam's $85 \%$ population lives in rural area, almost $75 \%$ of total population are still dependent on agriculture directly or indirectly. We can't hope for immediate big industrial investment for many reasons. Despite of laudable efforts by women entrepreneurs, the challenge of bringing more women into the economy is
\end{abstract}


still with the society as a whole and, the above women defied the situations exacerbated by COVID-19.

Keywords: Women entrepreneurships, Assam, COVID-19, Start-ups

\section{INTRODUCTION}

In the United States ${ }^{[1]}$ the first female owned business was recorded in the year 1739, when Eliza Lucas Pinckney took over the family's plantations business in South Carolina at the age of 16 years. However, this does not mean that there were no female entrepreneurs until $17^{\text {th }}$ century. In the eighteenth and nineteenth centuries, women used to run small businesses that has been attained through inheritance or created business opportunities to sustain livelihood. This happened due to lot many factors, including loss of income generating members, loss of spouse, poverty, or domestic violence. Those initiatives were never categorised as entrepreneurial but carried out as domestic responsibilities arising out of different situations. Nevertheless, those were women entrepreneurial initiatives that survived the onslaught of the adverse situations. During $18^{\text {th }}$ and $19^{\text {th }}$ century, many businesses flourished under the leadership of women, who have broken the barriers under the oppressions of society's existing limits and emerged into the centre stage. One such women is Rebecca Lukens, who in the year 1825, took over the family business, Brandywine Iron Works \& Nail Factory, and turned it into a profit-generating steel business. In the 1900s, due to a more progressive way of thinking, and the rise of feminism, female entrepreneurs began to be a widely accepted term. Women got their right to vote in the year 1920 and as society evolved, female entrepreneurs became more influential. With the boom of the textile industry and the development of the railroad and telegraph system, women such as Madame c J Walker took advantage of the development and was able to market her hair care products in a successful way, becoming the first African American female millionaire. On the other hand, another woman, Carrie Crawford Smith has become the owner of an employment agency opened in 1918.

\section{WOMEN ENTREPRENEURSHIPS}

In India Trend -Women: In India too, one of the first female entrepreneur is Kalpana Saroj ${ }^{[2]}$. At the age of 16 , she started working in a garment factory to support her family. She took a government loan earmarked for scheduled caste people and successfully started a tailoring business and than a furniture store. At the age of 16, she started working in a garment factory to support her family. Using government loans for scheduled caste people, she successfully started a tailoring business and then a furniture store. Kalpana Saroj started KS Film Production and produced first movie which was dubbed in English, Telugu and Hindi. Kalpana Saroj, a Padmashree award recipient in the year 2013, built up a successful real estate business, and was on the board of Kamani Tubes when it went into liquidation in 2001, and after taking over the company, restructured it and brought it back to profit. According to a report her net worth is USD 112 Million.

Likewise in Assam, the entrepreneurship ventures initiated by female were conspicuous too. Despite of having several matrilineal tribes, a few have been known on female business owners. In the late 1890s, in a small town in Jorhat, a few women entrepreneurs flourished. Muslim women, especially Kabuli and Irani women were at the forefront of business enterprise in Jorhat in late 1890s. When the Royal Air Force, selected the site of Rowriah Airbase (Later Indian Air Force's first airbase in the east), a khasi lady named Deria from Cinamara took the contract of constructing the airbase Thus women entrepreneurships flourished since early days in this part of the region. Moreover, historically the eastern part of India, especially in Northeast, women used to rank high in their social strata, and 
worshipped too. Women as deity or Goddess has been worshiped since early days and so prevalence of Debi's (Women Goddess) persists over male God, here in this part of the region. It is in this backdrop the spirit of women entrepreneurship of Assam has been evolved defying all odds amidst covid-19. The study is basically based on both primary and secondary sources of data ${ }^{[3,4]}$.

'The World has long been a man's world, where women have the legal status of children'. The popular belief has long been holding on for many countries, but not anymore. There are defying trends of women entrepreneurs and the article emphasises trends among the women entrepreneurs of Assam amidst covid-19 pandemic.

The Global Trend -Women: Around the world, the opportunities for women to lead successful, financially secure lives are being limited by government legislation, company policies and deeprooted misogyny. The UN is leading efforts to give women more access to digital financial tools, seen as essential to playing a full part in the global economy ${ }^{[5]}$.

This quote from the Women and Money report, published by the Gates Foundation, says it best: "Money is the domain of men. Society doesn't view it as [a woman's] role to earn money, or her right to make financial decisions". This is true for many of the countries we work in. According to UNThe statistics show that, in so many ways, women and girls bear the brunt of the digital divide: they are $12 \%$ less likely to own a phone than men, 35\% less likely to have internet access and $32 \%$ less likely to have access to energy. And, in least developed countries, women traditionally do not have access to the digital assets, collateral, networks, or financial services that can help them access the capital they need to start a business.

According to an UN report that states that - "Policy is also keeping women back: there are 115 economies where laws prevent women from running a business in the same way as men, and 167 countries that have at least one law restricting women's economic opportunity. On top of these challenges, most of the country's UNCDF works in do not mandate the use of sex-disaggregated data (i.e. data that identify whether the information concerns a man or a woman) in the private sector, which would encourage both the public and private sector to make data-based decision-making that can increase the number of women clients."

A few countries have specific laws that prevent women to work in certain areas citing 'Suitable Nature' or 'Suitable Place of work'. In Saudi Arabia, the law land of the law specifies that women may work only in "fields suitable to their nature" and prohibits them from jobs considered "detrimental to health" or "likely to expose women to specific risks". In practice, these opaque rules are often interpreted by employers as a means of banning women from anything physically challenging. (At the Luna factory, tasks such as moving heavy boxes are restricted to the men's section.) A Women in the Workplace initiative, launched in January, requires that women be given separate spaces to work if they ask for them; prevents women from being left alone with male colleagues; and mandates that women can work as cleaners or in room service only at all-female hotels or resorts. However, in an Indian scenario, no such restrictions are there and women are free to choose their choice of livelihood.

Women entrepreneurship in Assam amidst covid-19: The world economy is in the process of economic revival after the tarnishing effect of the Covid-19 pandemic including Assam. Homecoming picture of lakhs of migrants raised the question of how much capable the Assam economy is of employing this huge workforce. From the picture of organized rural agri economy reflected in the concept like "Gohalit goru, pukhurit maas, barit tamol-pan”, Momai Tamuli Barbaruah's economic idea of self-reliant family, to organized handicrafts industries in various parts reflects idea/sentiments 
of self-reliable Assam economy in the past. Momai Tamuli Barbarua made it compulsory for every adult able bodied female to spin a certain quantity of yarn every day. Record like Edward Gait's 'A History of Assam' says that handicarft industry was highly developed during Ahom period. Selfsufficiency had been the key-note of Assam's economy in medieval time also. It is worth mentioning her that, in the year 1950-51, per capita income in Assam was 4\% above national average ( Planning Commission, 2002). The women brigade of entrepreneurs of Assam has taken plunge into the world of business and defying all odds they have come up victorious.

Assam's $85 \%$ population lives in rural area, almost $75 \%$ of total population are still dependent on agriculture directly or indirectly. We can't hope for immediate big industrial investment for many reasons. So, the key for rural economy boost is the small-medium industries and an organized effective production-market chain, specially Agri-based small scale industry like food processing units with higher density to transform this huge workforce participation in agriculture and allied sector into economic growth in real sense.

It is hard to beat a person who never gives up. Defying all odds, the start-up ventures by the indigenous brigade have gained momentum and become success stories for the rest to follow.

Achievements of the young women entrepreneurs are an inspiration to many educated unemployed youth in Assam and the northeast to explore new innovative ideas and become self-reliant. India needs 100 million new jobs by 2026 for country's growth. Such a gigantic target cannot solely be achieved through existing jobs or business as usual, but only through creating self-employment and entrepreneurship-driven employment.

This is in this context the spirit of these young entrepreneurs and their successful ventures during lockdown period are to saluted. Each of their works would require a book form, to explain to the readers of their journey so far. However, an attempt has been made to write a few lines about them.

> Gaurav Medhi and Drishti Medhi, QuickGhy, a startup engaged in utility services. During pandemic period, they provided excellent services to the house hold and even took the risk to senitizes the residence of Covid patients, flats, etc .

$>$ Mukul Barma and Jintirani Deka, Quickfix, a startup, engaged in utility services and provided services to the guwahatians as well, during pandemic period.

$>$ Kashmiri Borkakati Nath, KATA Food, is a self-taught Chef with a national repute. She started her career more than 25 years back as a free launcher, having expertise in Assamese Cuisine and baking and tried to promote it in all over India. She was frequently invited by five star Hotels and top restaurants across India to curate their menus. She was the recipient of prestigious Goldman Sachs 10000 women entrepreneurial programme at ISB , Hyderabad. During pandemic she started her Startup KN Order- for bakery and KATA Food . KATA Food is ready-to-cook, fresh and pre marinated chicken prepared with hygienic condition. Teriyaki Chicken wings, BBQ Smoked drumstick, Creamy Afghani Murg, Awadi Chicken Korma and Chicken Tikka masala, are the major range of products now available under KATA Food.

> Subhalakkshmi Kataky, D Jonaks a 'Home Maker' turned 'Home Baker', she turned the disaster into opportunity, by starting her enterprise 'D JONAKs'- the essence of happiness at Guwahati during the lockdown period. During this unprecedented hour of crisis, a home 
maker was highly impressed with the clarion call "Aapda ko avsar mein badal dalon" made by Prime Minister Narendra Modiji.

$>$ Uttam Teron and Aimoni Tumung, Parijat Academy, started a school called Parijat Acdemy way back in 2003 at Pamohi in the outskirt of Guwahati for under privilege children of Pamohi area. These students belong to families of daily wage earners, rickshaw puller, workers of brick fields, stone query, industries, etc. There are about 550 students now in their school, from class KG to 10th standard. The school functions through donation from various charitable organizations. Aimoni is known as Pad Women of Assam. During pandemic, they started a Handloom unit as a startup venture and gaining ground defying all odds. The venture have employed local girls who in tern provides training to newly recruited people.

$>$ Prerona Das, Palasbari, Guwahati. She is making Masks from Assamese traditional cotton Gamocha during the Covid-19 pandemic. The initiative was widely appreciated by the media and people, as the medicated masks were not available in the initial period of the ill-fated pandemic. A large number of people use and benefited from such kind of local mask, which is beautiful in look at, is cost effective and durable .

\section{CONCLUSION}

Despite of laudable efforts by women entrepreneurs, the challenge of bringing more women into the economy is still with the society as a whole and, the above women defied the situations exacerbated by COVID-19.

\section{REFERENCE:}

1. UN : United Nations Website

2. Planning Commissions Report.- Govt of India

3. Dr. D. D. Mali, Dhanjit Medhi : Become a successful Entrepreneur, Biswa Foundation, 2018

4. The Naked Truth : Margaret Heffernan, published by Jossey Bass, 2004

5. Successful women Entrepreneurs of Assam : Industries and Commerce Department, Govt of Assam 2018

\section{* Corresponding Author: Ms.Rupamoni Saikia}

Assam Rajiv Gandhi University of Cooperative Management, Sivasagar, Assam, India

Online date of publication: 31.08.2021 